\title{
Broad-scale mapping of seafloor habitats in the north-east Atlantic using existing environmental data
}

\author{
Vasquez Mickael ${ }^{1,}{ }^{*}$, Mata Chacon D. ${ }^{2}$, Tempera Fernando ${ }^{3}$, O'Keeffe Eimear ${ }^{4}$, Galparsoro Ibon ${ }^{5}$, \\ Sanz Alonso J. L. ${ }^{2}$, Goncalves Jorge M. S. ${ }^{6}$, Bentes Luis ${ }^{6}$, Amorim Patricia ${ }^{3}$, Henriques Victor ${ }^{7}$, \\ Mcgrath Fergal ${ }^{4}$, Monteiro Pedro ${ }^{6}$, Mendes Beatriz ${ }^{7}$, Freitas Rosa ${ }^{8,9}$, Martins Roberto ${ }^{8,9}$, \\ Populus Jacques ${ }^{1}$
}

\begin{abstract}
1 Ifremer Centre Bretagne - ZI de la Pointe du Diable - CS 10070-29280 Plouzané, France 2 Instituto Español de Oceanografía - Corazón de María n 828002 Madrid, Spain

3 IMAR, Department of Oceanography and Fisheries, University of the Azores, Rua Prof. Dr. Frederico Machado, 4, 9901-862 Horta, Açores, Portugal 4 Marine Institute, Rinville, Oranmore, Co. Galway, Ireland ${ }_{5}$ AZTI-Tecnalia, Marine Research Division, Herrera Kaia, Portualdea s/n, 20110 Pasaia, Spain ${ }_{6}$ Centre of Marine Sciences (CCMAR), Universidade do Algarve, Ed. 7, Campus de Gambelas, 8005139 Faro, Portugal 7 Instituto Português do Mar e da Atmosfera, Avenida de Brasilia, 1449-006 Lisboa, Portugal 8 Department of Biology \& CESAM, University of Aveiro, 3810-193 Aveiro, Portugal

* Corresponding author : Mickael Vasquez, email address : $\underline{\text { Mickael.Vasquez@ifremer.fr }}$

dulce.mata.chacon@ucm.es ; fernando.tempera@jrc.ec.europa.eu ; Eimear.okeeffe@marine.ie , igalparsoro@azti.es ; jsanz_a1@md.ieo.es ; jgoncal@ualg.pt ; Ibentes@ualg.pt ; pamorim@uac.pt ; victorh@ipimar.pt ; fergal.mcgrath@marine.ie ; pmontei@ualg.pt ; bmendes@ipimar.pt ; rosafreitas@ua.pt ; roberto@ua.pt ; Jacques.Populus@ifremer.fr
\end{abstract}

\begin{abstract}
:
If marine management policies and actions are to achieve long-term sustainable use and management of the marine environment and its resources, they need to be informed by data giving the spatial distribution of seafloor habitats over large areas. Broad-scale seafloor habitat mapping is an approach which has the benefit of producing maps covering large extents at a reasonable cost. This approach was first investigated by Roff et al. (2003), who, acknowledging that benthic communities are strongly influenced by the physical characteristics of the seafloor, proposed overlaying mapped physical variables using a Geographic Information System (GIS) to produce an integrated map of the physical characteristics of the seafloor. In Europe the method was adapted to the marine section of EUNIS (European Nature Information System) classification of habitat types under the MESH project, and was applied at an operational level in 2011 under the EUSeaMap project. The present study compiled GIS layers for fundamental physical parameters in the northeast Atlantic, including (i) bathymetry, (ii) substrate type, (iii) light penetration depth and (iv) exposure to near-seafloor currents and wave action. Based on analyses of biological occurrences, significant thresholds were fine-tuned for each of the abiotic layers and later used in multi-criteria raster algebra for the integration of the layers into a seafloor
\end{abstract}


habitat map. The final result was a harmonised broad-scale seafloor habitat map with a $250 \mathrm{~m}$ pixel size covering four extensive areas, i.e. Ireland, the Bay of Biscay, the Iberian Peninsula and the Azores. The map provided the first comprehensive perception of habitat spatial distribution for the Iberian Peninsula and the Azores, and fed into the initiative for a pan-European map initiated by the EUSeaMap project for Baltic, North, Celtic and Mediterranean seas.

\section{Highlights}

- Spatial seafloor physical characteristics data for the NE Atlantic was compiled. Datasets were harmonised to common standards prior to input into a GIS environment. The inputs were overlaid via spatial analyses to derive a broad-scale habitat map. Habitats were described following the marine section of EUNIS habitat classification. Biologically-relevant thresholds were established for delineation of EUNIS categories.

Keywords : Habitat Mapping, EUNIS, Exposure, Biological Zones, Substrate 


\section{Introduction}

The demand for accurate and reliable maps describing the seafloor habitats of Europe has increased dramatically in recent years with the implementation of legislation such as the Habitats Directive (92/43/EEC) and the Marine Strategy Framework Directive (MSFD; 2008/56/EC). Such information is crucial for the production of broad-scale maps of human impact on the marine environment (Andersen et al., 2013; Halpern et al., 2008). Marine spatial planning also demands reliable and comprehensive spatial data that includes the characteristics of coastal and ocean environments based on habitat types (e.g. Douvere et al., 2007; Gilliland and Laffoley, 2008).

Habitat mapping typically relies on the application of multiple survey techniques such as single- and multi-beam sonar, LiDAR, grab sampling and other physical ground-truthing, to derive data that can be integrated to produce a map (Brown et al., 2011). To date, numerous international protected areas programs (e.g. Natura 2000 network established under the Habitats Directive) as well as other local initiatives (e.g. Ehrhold et al., 2006; Galparsoro et al., 2013; Gorman et al., 2013; Todd and Kostylev, 2011) have used these different approaches to produce spatially explicit maps. These methods allow detailed maps to be developed: the boundaries between adjacent habitats are accurately delineated, and both the abiotic characteritics and the associated biological communities are described. Their drawback is that they are costly, resource-intensive and time-consuming, typically taking around three years from the first survey to full map completion. Therefore it is impractical to apply such an approach to all points on the seafloor in order to achieve full spatial coverage across Europe.

Broad-scale mapping represents an alternative to the piecemeal approach described above, the benefits of extended map coverage at reasonable cost. The concept relies on the assertion that benthic communities are strongly influenced by the physical characteristics of the seafloor (e.g. type of sediment, or slope) and the water column (e.g. temperature or water movement; Glémarec, 1973). Acknowledging this, Roff et al. (2003) proposed overlaying mapped physical variables using a Geographical Information System (GIS) to produce an integrated map of the physical characteristics of the seafloor, which they termed 'seascapes'. This method, which was successfully tested for the entire Canadian coastline (Roff et al. 2003), can be used to produce maps that, while less detailed, are of greater spatial extent and considerably less costly as they are based on existing information.

The capacity to rapidly augment spatial data in a very cost effective way is leading to a profound and rapid uptake of broadscale mapping approaches. The approaches have been widely adopted, particularly in Australia (Harris et al., 2008; Huang et al., 2011) and in Europe, where it was first investigated at a continental scale as part of the INTERREG MESH project, which adapted the method to the European EUNIS (European Nature Information System) classification scheme (Coltman et al., 2008). Following on from this, the EUSeaMap project successfully put the method into practice for the western Mediterranean, Celtic, North and Baltic Seas (Cameron and Askew, 2011). Simultaneous national initiatives, in France (Hamdi et al., 2010) and in the United Kingdom (UKSeaMap 2010 project, McBreen et al., 2011), also applied this method successfully.

The present study was carried out within the framework of the MeshAtlantic project funded by the INTERREG 'Atlantic Area 2007-2013' program. A key output of the project was a broad-scale map for four extensive areas around Ireland, the Bay of Biscay, the Iberian Peninsula and the Azores islands. The goal of this output was clearly to feed into the initiative for a panEuropean map initiated by the EUSeaMap project. In order to be compatible with the results of EUSeaMap, the same methodology for generating a broad-scale map was used. A particular effort was dedicated to the selection of ecologically significant thresholds for the categories considered by the EUNIS classification using groundtruthing data. 


\section{Material and methods}

\subsection{Study area}

The region covered is an area of about 2 million $\mathrm{km}^{2}$ which includes the Atlantic waters of continental Europe and the Portuguese archipelago of the Azores (Fig. 1). It specifically includes the Iberian Peninsula, the Bay of Biscay, the Irish Sea, the Celtic Sea, and the seas surrounding the Azores islands. Although the Western Channel Sea and western part of the Irish sea were within the geographic bounds of the EU's 'Atlantic Area 2007-2013' program (http://www.seupb.eu/programmes20072013/interreg-overview/transnational/atlanticareaprogramme.aspx) which funded the present project, they were not specifically targeted in this project as they had already been mapped within the framework of the EUSeaMap project (Cameron and Askew, 2011), and no improvement of the data for those areas had been identified since that time.

The area includes a diverse range of environmental conditions. At the scale of the entire area sea temperature and water depth are the main features determining seafloor species geographical distribution. Dinter (2001) separates the shelf and upper slope (for depth up to $1000 \mathrm{~m}$ ) into three biogeographic zones, from North Shetlands Isles southward (i) the Boreal Lusitanean which comes down to a parallel across the English Channel, (ii) the Lusitanean Boreal extending downwards to roughly the Gironde Estuary in the Bay of Biscay and (iii) the Lusitanean extending to Gibraltar. The latter is divided into a warm subprovince covering the Aquitaine and the Basque Country in the north of Spain and an area in the south composed of the southern Portuguese coast and the Gulf of Cadiz. Due to the presence of strong upwelling, the central part of the Iberian Peninsula from Cantabria to Cape St Vincent is referred to as the cool Lusitanean subprovince. In this province, where the inshore area is dominated by rocky substrate, cold nutrient-rich water induces the presence of invertebrates and macroalgae usually found more to the north (e.g. Martins et al., 2013). Shelves and upper slopes in the Azores archipelago are put into a category of their own belonging to the Macaronesia province.

At finer scales the influence on community composition / species distribution of more specific water quality parameters along with seafloor topography, substrate and exposure to water movement become significant. Broad areas of shallow waters (light grey tones in Fig. 1) occur all around Ireland (west of the Porcupine Bank and in the southern part of the Celtic Sea) and in the western Bay of Biscay (French continental shelf), while off the coasts of northern Spain, the Iberian Peninsula and the Azores, deep-sea areas (dark grey tones in Fig. 1) are much more extensive nearshore. The Azores, a volcanic archipelago straddling the Mid-Atlantic Ridge, are noteworthy for the complexity of their geomorphology with nine islands and numerous seamounts, as well as for the prevalence of deep-sea grounds. Another deep-sea zone is the offshore Rockall Trough, which is located to the northeast of Ireland and in some places extends over $300 \mathrm{~km}$ in width and to depths of over $3000 \mathrm{~m}$. From an oceanographic perspective, current-induced flows are generally weak except in the shallow, semi-enclosed Irish Sea, in local areas of the Northeastern French coast and near the Gibraltar Strait. The northeast Atlantic is known for its rough seas due to large storms that occur during the winter months. 


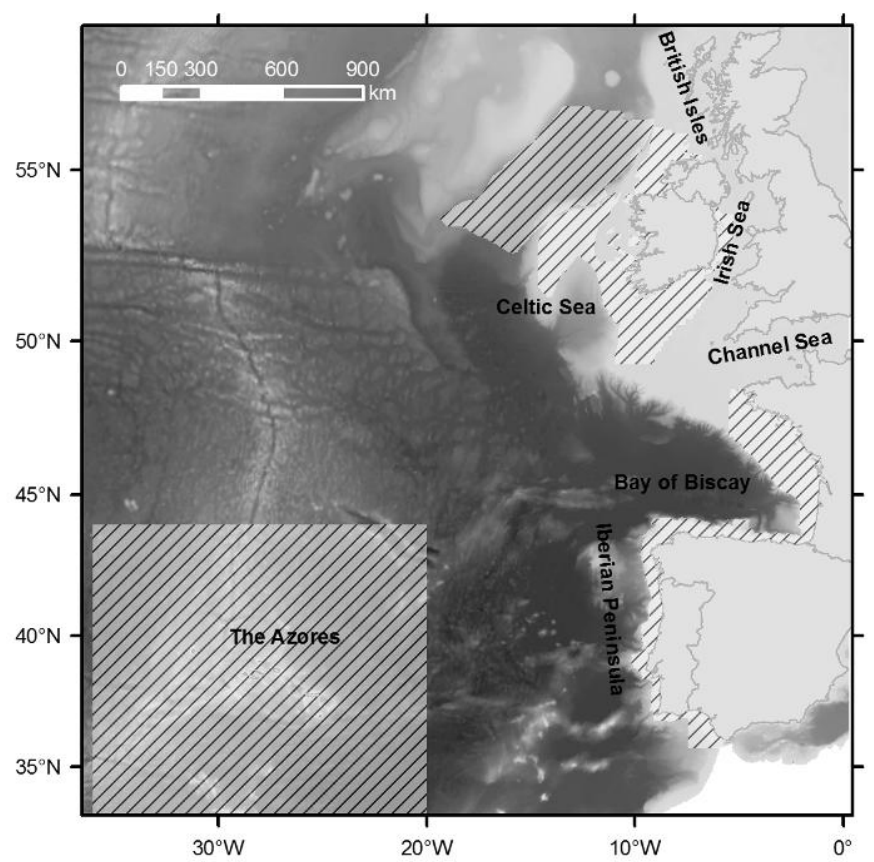

Fig.1. NE Atlantic area. The hashed area shows the coverage of existing data.

\subsection{Method overview}

\subsubsection{Classification scheme}

The term 'habitat' is now generally accepted to mean "a place where plants or animals normally live, characterised primarily by its physical features (topography, plant or animal physiognomy, soil characteristics, climate, water quality etc.) and secondarily by the communities of plants and animals that live there" (Davies et al., 2004). A habitat description must be based on a common habitat classification system, the function of which is to provide a common language and ensure cross-boundary consistency (i.e. particularly when spanning different countries). A number of habitat classifications schemes have been developed at regional or local scales. Most published examples of broad-scale mapping have also proposed their own classification (see e.g. Huang et al., 2011; Roff et al., 2003; Zacharias et al., 1999), but rarely were these reused by other authors.

In Europe, the EUNIS (European Nature Information System) classification, which provides a common European reference set of habitat types for terrestrial, freshwater and marine habitats (Davies et al., 2004), facilitates reporting of habitat data in a comparable manner, for use in nature conservation (e.g. inventories, monitoring and assessments), habitat mapping and environmental management. It is thus considered today as a reference tool within a European context. The current structure of the marine section of EUNIS covers a wide range of habitat types; even though it was first derived from the BioMar classification developed for Britain and Ireland (Connor et al., 1997 ${ }^{\mathrm{a}}, 1997^{\mathrm{b}}$, and 2004), substantial efforts have been made to include information on marine benthic habitats from different regions, aiming to provide a comprehensive geographical coverage of European seas (Galparsoro et al., 2012). It was successfully used for broad-scale mapping purpose by the MESH (Coltman et al., 2008) and EUSeaMap (Cameron and Askew, 2011) projects. For these reasons EUNIS was an obvious choice for the present study. 


\subsubsection{Mapping approach}

The marine part of the EUNIS habitat classification starts from level 1, where it is named 'A: marine habitats'. The following levels (2,3 and to some extent 4) describe the physical (or abiotic) factors of the habitat, that can be likened to the 'physical features' in the definition of the term 'habitat' given in the previous section. For example in the infralittoral zone, characterised by rocky substratum and a high degree of exposure to hydrodynamic forces the habitat is named 'A3.1: High energy infralittoral rock'. When the abiotic characteristics of the habitat are fully defined the biotic environment of the habitat, i.e. its dominant vegetal or animal communities, starts to be described in lower levels (4 or 5 to 6 ).

Broad-scale mapping as developed within the MESH project and as performed in our study aims to make maps at physical levels of the marine section of EUNIS, i.e. at levels 3 or 4 (Coltman et al., 2008). EUNIS uses three basic characteristics to differentiate among, and so classify, marine habitats. Firstly the 'biological zone' (e.g. infralittoral, circalittoral and deepcircalittoral zones) which is a vertical zonation reflecting changing conditions of light penetration/attenuation and disturbance of the seabed by wave action, which together influence habitat suitability for many plant and animal species. Secondly the substrate type (e.g. rock, sand, mud), which dictates habitat suitability for many organisms. Thirdly, for rock habitats only, there is also consideration of the energy regime, a qualitative indication of the relative exposure to hydrodynamic forces induced by waves and/or currents (i.e. high, moderate and low energy environments). These three characteristics can be represented in a GIS by separate data layers, and combined using simple spatial algebra to create a habitat map layer (Fig. 2), classified according to the upper levels of the EUNIS system (e.g. level 3 for rock and level 4 for sediments). The process is carried out in raster mode, because most raw datasets describing physical variables are provided in a raster format and because the cell-based map algebra language (Tomlin, 1990) is the most convenient way to overlay and perform calculations on oceanographic GIS layers. Sought pixel size for the final broad-scale habitat raster layer was $250 \mathrm{~m}$, which is roughly equivalent to a scale of $1: 1,000,000$.

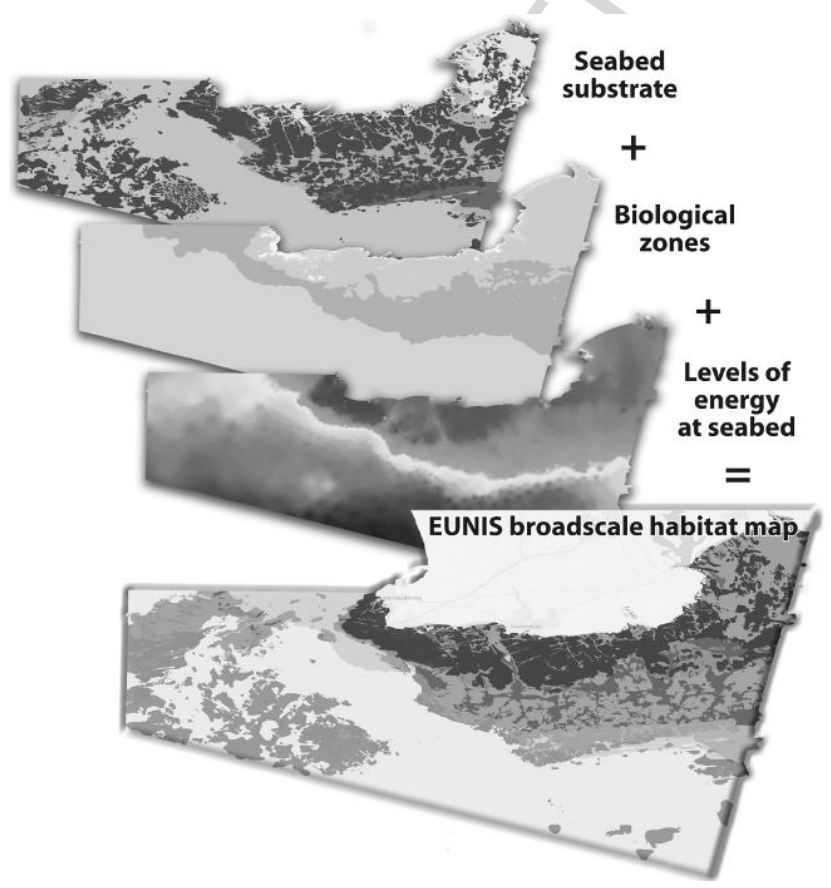

Fig. 2. Schematic representation of the methodology, which involves the combination of three raster base-layers (i.e. the types of substrate, the biological zones and the hydrodynamics-induced energy levels at the seafloor) to produce a EUNIS habitat map describing the physical environment. 


\subsubsection{Computing climatology}

Some of the variables used for modelling (i.e. light penetration and exposure to hydrodynamic forces) display considerable variation over time (e.g., seasons). Therefore, they need to be integrated over long periods in order to derive general trends. For such time-dependent variables, the choice of an appropriate metric is an important issue to consider. There is a general consensus that extreme events such as storms strongly influence the spatial distribution of habitats (because of the magnitude of destruction) and therefore the 'maximum' metric should be used to capture spatial patterns. The authors of this study argue to the contrary, recommending that this metric should not be used in the context of broad-scale habitat mapping whose purpose is to be as generalised as possible, i.e. to present where habitat boundaries are likely to be located considering the normal (i.e. not extreme) environmental conditions. Since an average value can be influenced greatly by outliers (e.g., extreme environmental events), the use of a relevant percentile (in this case the $90^{\text {th }}$ percentile) was chosen as a means of filtering out such extreme events.

\subsubsection{Defining thresholds}

The marine section of EUNIS system uses qualitative descriptors for most abiotic characteristics of habitats, such as the high, moderate and low energy categories for energy regime. However, the GIS approach requires quantitative values to define thresholds/boundaries between adjacent classes, such that spatial algebra is performed in an objective, consistent and repeatable manner.

The threshold values were derived from known biology (based on the statistical analyses of field-observations of habitat type). In the optimal situation, where samples on both side of a given boundary (e.g. boundary between the infralittoral and the circalitoral biological zones) were available, the Receiver Operating Characteristic (ROC) curve (Pearce and Ferrier, 2000) from the ROCR R package (Sing et al., 2005) was used. This tool is commonly used by ecologists for validation of predictive distribution models (e.g. Dunn and Halpin, 2009; Gorman et al., 2013; Roberts et al., 2010). It can also be used, as it is widely done for medical tests (Kumar and Indrayan, 2011), for the determination of the optimal threshold value for any variable having a high discriminatory capacity to differentiate one category from another.

\subsection{Derivation of the seafloor substrate layer}

A full-coverage seafloor substrate layer, describing all the types of substratum recognised by the marine section of EUNIS classification, was an integral part of the study. In order to be EUNIS-compliant, the layer had to comprise a rock class and six sediment classes: coarse sediment, mixed sediment, sand, muddy sand, sandy mud and mud. Polygon layers were collated from a variety of sources across the study area, from historical maps derived only from extrapolation of sample point data to more recent maps produced with the help of geophysical methods that provided a higher density of information. The challenge was in integrating datasets that were quite diverse in terms of scale and sediment classification. For that purpose a classification built on that of Folk (1954) and taking into account the study area sediment characteristics was proposed (Mata Chacón et al., 2013). All datasets were translated into the aforementioned sediment classification, which sometimes necessitated the use of expert knowledge or of existing sample points for groundtruthing. In the case of the Azores, most information was available as sample point data. As a result, in a first phase a geology expert interpretation based on the substrate data points and the underlying topography was used to extrapolate point data into polygon units. This approach was later complemented by statistical modelling to cover the uninterpreted areas left by the expert. 


\subsubsection{Definition}

It was recognised early in the history of studies describing marine habitats that the distribution of benthic communities is strongly correlated with the environmental conditions on the seafloor (e.g. Glémarec, 1973; Pérès and Picard, 1964). This led European marine ecologists to divide the seafloor into zones, cited as 'biological zones' in the EUNIS classification.

EUNIS currently takes into account the zones occurring on the continental shelf in the following sequence with increasing depth: the infralittoral, the circalittoral, and the deep circalittoral. In contrast to this, the area from the continental slope to the abyssal plain does not have any individual zones, instead the area is grouped into a single block, termed 'deep-sea', a situation that is acknowledged to be too restrictive for a zone characterised by such a rapid change in depth (and other related parameters such as temperature), and for which faunal zones have been defined by numerous authors (for review see Carney et al., 1983). This lack of appropriate division within EUNIS for the deep sea led Howell (2010) to propose a biologically-relevant division of the deep-sea bottom for the northeast Atlantic into five zones, ranked from shallowest depth: upper slope, upper bathyal, midbathyal, lower bathyal, and abyssal. For the present research, this classification of deep-sea seafloor was adopted as it was considered appropriate for the study area.

\subsubsection{The bathymetry layer}

Bathymetry is a crucial data layer required for the generation of all GIS layers used as proxies for biological zones. A good quality bathymetry layer was therefore of paramount importance to the present study. The best available datasets were collated from a variety of national or local sources (i.e. sounding points or high resolution digital elevation models). In areas where detailed information was lacking, i.e. off the Azores, the Gebco 30 arc-second gridded bathymetry layer (Gebco_08 version) was used. Data providers were requested to reference their data to local Chart Datum, which is an approximation of lowest astronomical tide (LAT), while the Gebco is referenced to mean sea level (MSL). This default of the bathymetry layer was deemed acceptable as it concerned the offshore part of the Azores only. The datasets were combined into a full-coverage raster layer covering the entire study area at a resolution of 250m (Mata Chacón et al., 2013).

\subsubsection{Infralittoral - circalittoral boundary}

The infralittoral zone extends from a boundary where the seafloor is rarely uncovered to a boundary that marks the end of favorable light conditions for the growth of seagrass and other macrophytes. The dominance of seagrass and green algae ends at the transition into the circalittoral zone, where sciaphilic algae that can tolerate low light conditions dominate. A full coverage layer describing light conditions is therefore required to accurately define the boundary between these two zones. Light attenuation, which increases with turbidity, can be quantified via the diffuse attenuation coefficient of the photosynthetically available radiation $\left(\mathrm{k}_{\mathrm{dPAR}}\right.$, expressed in $\mathrm{m}^{-1}$, see Saulquin et al., 2013). The advantage of this measure is that it is routinely derived from readily available ocean color satellite sensors. A $250 \mathrm{~m}$ resolution raster layer that gave mean values for $\mathrm{k}_{\mathrm{dPAR}}$ over a five-year period (2005-2009) was used in the study. The layer was derived from archives of radiance values measured by the European MERIS (Medium Resolution Imaging Spectrometer Instrument) sensor. This work was performed within the framework of EUSeaMap project for a large area of European coastal waters (Saulquin et al., 2013), and for the purpose of this study the equivalent information was computed for the Azores. 
The fraction of surface light (Fr) that reaches a given water depth, h, is estimated by a form of the Lambert-Beer law:

$\mathrm{Fr}=\mathrm{e}^{-\mathrm{kdPAR} \times \mathrm{h}}$

Thus the fraction of surface light that reaches the seafloor is obtained by substituting into the equation the depth given by the bathymetry layer and the $\mathrm{k}_{\mathrm{dPAR}}$ raster layer.

Ecologists have long acknowledged that the boundary between the infralittoral and the circalittoral relates to the threshold at which $1 \%$ of surface incident light reaches the seafloor (i.e. Fr=0.01; Castric-Fey et al., 1973; Lüning and Dring, 1979; Pérès, 1967). Recent studies confirmed this value (Cameron and Askew, 2011; Saulquin et al., 2013). Studies on the presence of algae from sample points were conducted in both mainland Portugal and the Azores as part of the present study, the findings of which fundamentally confirmed the $1 \%$ of surface light cut-off value (see Amorim et al. for the Azores case study, in this volume).

\subsubsection{Circalittoral - Deep circalittoral boundary}

In contrast to the circalittoral, the deep circalittoral is a zone in which variations in water motion and temperature are minimal due to the reduced exposure of the seafloor to hydrodynamic forces (Glémarec, 1973). A commonly used approach to predict the upper limit of the deep circalittoral relies on the notion of wave base, which can be defined as the depth at which the seafloor is no longer disturbed by wave action. The theory defines that depth, $h$, is equal to half the wave length, $\lambda$, of the surface waves. The boundary between the circalittoral and the deep circalittoral can therefore be defined by the formula $\lambda / \mathrm{h}=2$.

A gridded layer describing wave length was computed from peak wave period given by archived time-series data of wave prediction models developed by Ifremer (Roland and Ardhuin, 2014), the University of the Azores and the University of Lisbon. The approximation to the dispersion relation used for the derivation of wave length from peak wave period and depth was that proposed by Guo (2002). The raster layer was prepared at a spatial resolution of $4 \mathrm{~km}$, over a time period of three years (20102012) for both coasts surrounding the Iberian Peninsula and the Azores, and six years (2006-2011) for the other regions included in the study. The values of $\mathrm{h}$ required for the calculation of the $\lambda / \mathrm{h}$ raster layer were extracted from the bathymetry raster layer.

As part of the present study, the theoretical threshold $\lambda / \mathrm{h}=2$ was tested with the help of observed sample data from which Glémarec (1969) had previously defined the biological zone (i.e. 114 circalittoral and 118 deep circalittoral occurrences, see Fig. $3 \mathrm{~A})$. For each point the value $\lambda / \mathrm{h}$ was extracted from the corresponding gridded layer and the resulting data set was used in a ROC curve analysis to determine the optimal $\lambda / \mathrm{h}$ cut-off value which would separate the circalittoral from the deep circalittoral categories (Fig. 3B). This analysis yielded an area under the curve (AUC) of 0.94, which indicates that the variable has a high capacity to differentiate between the circalittoral and the deep circalittoral. The analysis indicated an optimal threshold value of $\lambda / \mathrm{h}=2.53$, i.e. the value that least misclassified both circalittoral and deep circalittoral occurrences. This value enabled $89 \%$ of circalittoral and $86 \%$ of deep circalittoral occurrences to be classified correctly. Sample points within other parts of the study area were unavailable; therefore this value was used for the entire area. The resulting boundary was scrutinized by experts in the various regions of the study area who, based on their local knowledge, deemed it consistent with what they would expect. 

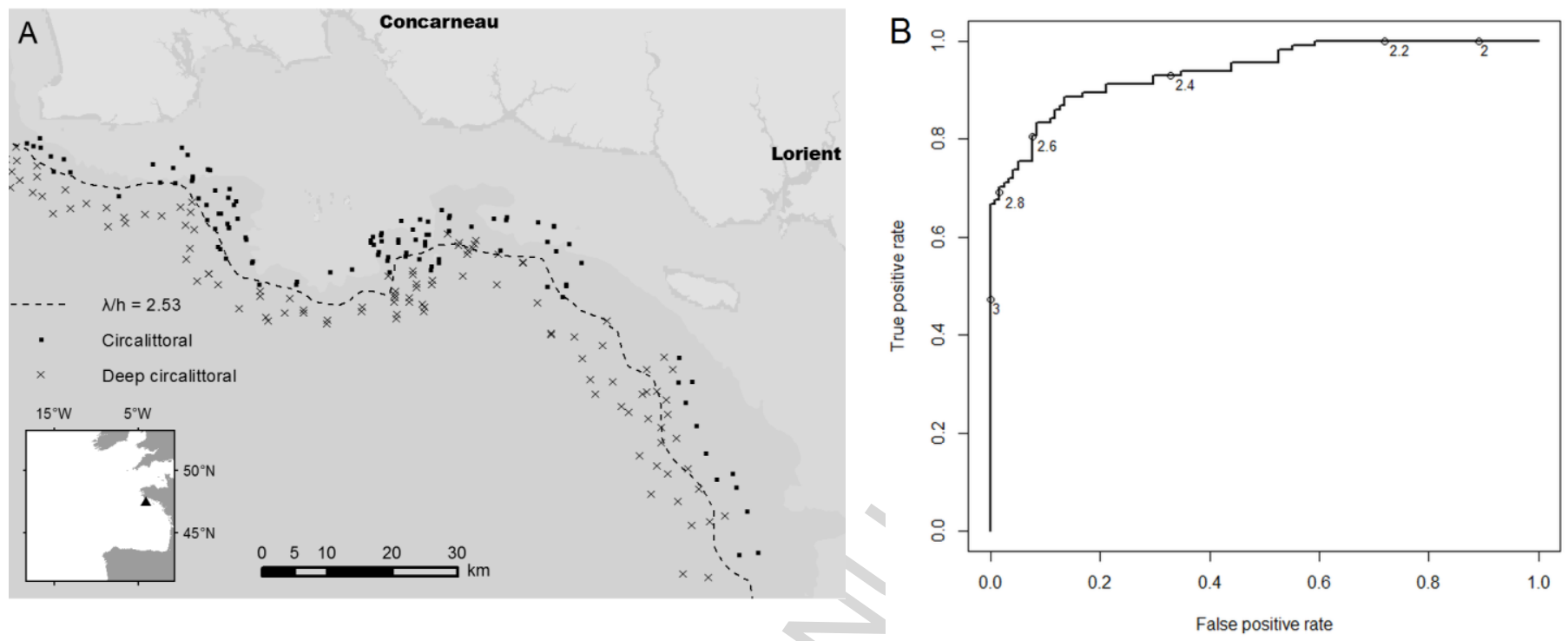

Fig. 3. Identification of the $\lambda / \mathrm{h}$ threshold used to delineate the transition between the circalitttoral and the deep circalittoral zones. (A) Map of the sample points used to construct the ROC analysis, and (B) ROC curve (along which $\lambda / \mathrm{h}$ values are displayed), which led to a decision threshold value of $2.53(\lambda / \mathrm{h})$. This value gives the lowest rate of misclassification for both circalittoral and deep circalittoral occurrences (resp. true positive rate and 1-false positive rate axis on the graph). The corresponding isoline is also shown on (A) as a dashed line.

\subsubsection{Deep-sea zones boundaries}

Abrupt changes in slope were used to identify two deep-sea boundaries: i) the boundary between the deep circalittoral and the upper slope and ii) the boundary between the lower bathyal and the abyssal. Those were manually delineated by the visual interpretation of derivatives of the bathymetry layer which are i) slope, which by giving values of slope in degrees allowed for the identification of slope changes, ii) depth contours, which were extracted for every $5 \mathrm{~m}$ of depth, with slope changes inferred where isolines were close together, and iii) vertical profiles, which were used where the two other layers were not helpful, e.g. because of local complexity in the geomorphology. This work was carried out by a geologist for the entire stydy area. The base of seamounts, which are characteristic features of the Azores and the western margin of mainland Portugal, were also delineated. The base of seamounts arising from the abyssal plain was considered as a slope change, and thus was interpreted as a boundary between the bathyal and the abyssal.

The three limits separating the other deep-sea zones into upper slope, the upper bathyal, the mid-bathyal and the lower bathyal were defined based on the depth contours suggested by Howell (2010), with depth values of 750m, 1100m, and 1800m respectively.

\subsection{Derivation of the energy layer}

\subsubsection{Methodology}

The EUNIS classification system uses relative magnitude of exposure to hydrodynamic processes (waves and currents) to differentiate three classes of rock habitat (high, moderate and low energy rock). It does not extend this to sediment habitats as it is assumed that the grain size distribution at any one location (e.g. the specific proportions of cobble, pebble, sand and mud) will 
reflect the energy 'climate' (the heavier particles being prevalent in higher energy regimes and the lighter particles dominating low energy regimes). In order to prepare a gridded layer describing energy levels, the methodology developed by the EUSeaMap project (Cameron and Askew, 2011) was used. It was carried out in two steps: i) classification of a current-induced and a wave-induced energy layer into the three levels via separate thresholds (see Table 1), and ii) combining the two energy classification layers using a simple rule which states that the highest level of energy defined for each pixel by the two input layers is the level that is to be retained.

Table 1 - Kinetic energy thresholds $\left(\mathrm{N} . \mathrm{m}^{-2}\right)$ for EUNIS energy levels

\begin{tabular}{llll} 
Level & Currents & Waves $-\mathbf{4 k m}$ model & Waves $-\mathbf{3 0 0 m}$ model \\
\hline Low & $>1.16$ & $>0.043$ & $>0.13$ \\
Moderate & $0.13-1.16$ & $0.003-0.043$ & $0.0025-0.13$ \\
High & $<0.13$ & $<0.003$ & $<0.0025$ \\
\hline
\end{tabular}

\subsubsection{Compiling data for the energy layer}

The base layers were climatological layers of kinetic energy at the seafloor. This one is given by the equation

$\mathrm{E}\left(\mathrm{N} \cdot \mathrm{m}^{-2}\right)=1 / 2 \rho v^{2}$

where $\rho$ is the density of the water, taken here as $1.027 \mathrm{~kg} \cdot \mathrm{m}^{-3}$, and $\mathrm{v}$ is the water velocity at the seafloor, either waves orbital velocity (calculated using the peak wave period) or current speed.

The two layers were prepared by compiling a climatology computed from archived results from different models, the characteristics of which are described in Tables 2 and 3. It should be noted that the gaps were filled by a climatology computed within the framework of the UKSeaMap project (West et al., 2010).

Table 2 - Wave-induced climatological layers characteristics

\begin{tabular}{|c|c|c|c|}
\hline Area & Resolution & Time span & Source \\
\hline $\begin{array}{l}\text { Bay of Biscay, including northern } \\
\text { Spain and southern Irish sea }\end{array}$ & $\begin{array}{l}300 \mathrm{~m} \text { along shore } \\
3 \mathrm{~km} \text { offshore }\end{array}$ & 5 years & $\begin{array}{l}\text { Ifremer, IOWAGA project hindcast } \\
\text { archives (Roland and Ardhuin, 2014), } \\
\text { WAVEWATCH III }^{\mathrm{TM}} \text { model (Tolman, } \\
\text { 2009) }\end{array}$ \\
\hline Iberian peninsula & $4 \mathrm{~km}$ & 3 years & $\begin{array}{l}\text { Maretec, WAVEWATCH III }{ }^{\mathrm{TM}} \text { model } \\
\text { (Tolman, 2009) }\end{array}$ \\
\hline Azores & $4 \mathrm{~km}$ & 3 years & $\begin{array}{l}\text { University of the Azores, } \\
\text { WAVEWATCH III }{ }^{\mathrm{TM}} \text { model (Tolman, } \\
\text { 2009) }\end{array}$ \\
\hline Other areas & $\begin{array}{l}100-300 \mathrm{~m} \text { along shore } \\
12.5 \mathrm{~km} \text { offshore }\end{array}$ & 5 years & UKSeaMap project (West et al., 2010) \\
\hline
\end{tabular}


Table 3 - Current-induced climatological layers characteristics

\begin{tabular}{llll} 
Area & Resolution & Time span & Source \\
\hline $\begin{array}{l}\text { Bay of Biscay, including southern } \\
\text { Ireland }\end{array}$ & $700 \mathrm{~m}$ & 5 years & $\begin{array}{l}\text { Previmer platform archives, based on } \\
\text { Ifremer MARS2D model (Lazure et al., } \\
2009)\end{array}$ \\
$\begin{array}{lll}\text { Iberian peninsula and northern Spain } \\
\text { Azores }\end{array}$ & $4 \mathrm{~km}$ & 3 years & $\begin{array}{l}\text { Maretec, MOHID-PCOMS } \\
\text { archives (Mateus et al., 2012) }\end{array}$ \\
Other areas & $4 \mathrm{~km}$ & 3 years & $\begin{array}{l}\text { University of the Azores, MOHID- } \\
\text { PCOMS model archives }\end{array}$ \\
& $1.8 \mathrm{~km}$ along shore & 5 years & $\begin{array}{l}\text { UKSeaMap project (West et al., 2010) } \\
12 \mathrm{~km} \text { offshore }\end{array}$ \\
\hline
\end{tabular}

The process led to the creation of heterogeneous layers in terms of spatial resolution. A good resolution was achieved for some coasts while for others, namely the Iberian Peninsula and the Azores, it was not possible to reach a resolution better than $4 \mathrm{~km}$.

\subsubsection{Determining threshold levels}

The heterogeneity of the layers in spatial resolution generated complications for the calculation of thresholds for wave-induced energy. Along the coast, values of kinetic energy derived from the $4 \mathrm{~km}$ resolution models appeared to be considerably lower than values generated from the $250 \mathrm{~m}$ resolution models. This can be explained by the fact that coarse resolution models are not able to capture the along-shore wave breaks (which generate high energy) whereas fine resolution models can. Therefore, the coarse resolution model significantly underestimates the kinetic energy values in shallow waters. In conclusion, because of the differences in spatial resolution within the compiled kinetic energy layer, two sets of thresholds had to be calculated, respectively for a pixel size of $300 \mathrm{~m}$ and $4 \mathrm{~km}$.

Complications due to this heterogeneity were exacerbated by the difficulties in collecting habitat-type field sample data characterising wave-induced energy levels. An observation-based approach for determining the thresholds between the different energy classes was considered but was not successful in the Bay of Biscay due to the inherent difficulties and dangers associated with making field observations in high energy environments. Therefore the thresholds were defined with the help of the boundaries calculated for the EUSeaMap project map which described wave-induced energy levels in the Channel Sea, an area that was also covered in the gridded layer generated by the present study. In areas such as the coast of mainland Portugal a statistical analysis of Kelp sample data enabled the development of a set of thresholds (Monteiro et al., in this volume). These thresholds were also applied to the Azores, which shared the same resolution $(4 \mathrm{~km})$. In other areas, where the layer of waveinduced kinetic energy generated by the UKSeaMap project was used, the thresholds that were computed within that framework (McBreen et al., 2011) were applied.

Currents were classified according to the thresholds defined within the framework of the UKSeaMap project (McBreen et al., 2011). The validity of these thresholds could not be tested due to the absence of habitat field data characterising the various current regimes. They were applied to the gridded layer of current-induced kinetic energy and the spatial patterns were visually verified by experts for each region during a workshop. 


\subsection{Final step: constructing the habitat map}

After finalising the three primary layers the last step was to integrate them into the final habitat map. This process involved the addition of the three raster layers. As shown in Figure 4 energy levels were coded in units of one, substrate types in units of ten, and biological zones in units of hundred. Hence the sum of the 3 layers led to a three-digit coded layer, each code being representative of a unique combination of an energy level, a substrate type and a biological zone (e.g; '111' was the sum '1+10+100', which corresponded to the combination 'High energy'+'Rock'+'Infralittoral'). The resulting classification layer was then translated into EUNIS. For example the combination 'Infralittoral'+'Rock'+'Low energy' was translated into the EUNIS habitat 'A3.3: Low energy infralittoral rock'. For the deep-sea realm, as described in section 2.4.1, EUNIS was not applicable. For example the combination 'Upper bathyal'+'Mud'+'Low energy' was not translated into the overly restrictive EUNIS habitat 'A6.5: Deep-sea mud' but into the non-EUNIS habitat 'Upper bathyal mud'.

This led to a final habitat map comprising 47 habitats, from which 22 were EUNIS classes and 25 of which were new deep-sea habitat types. 

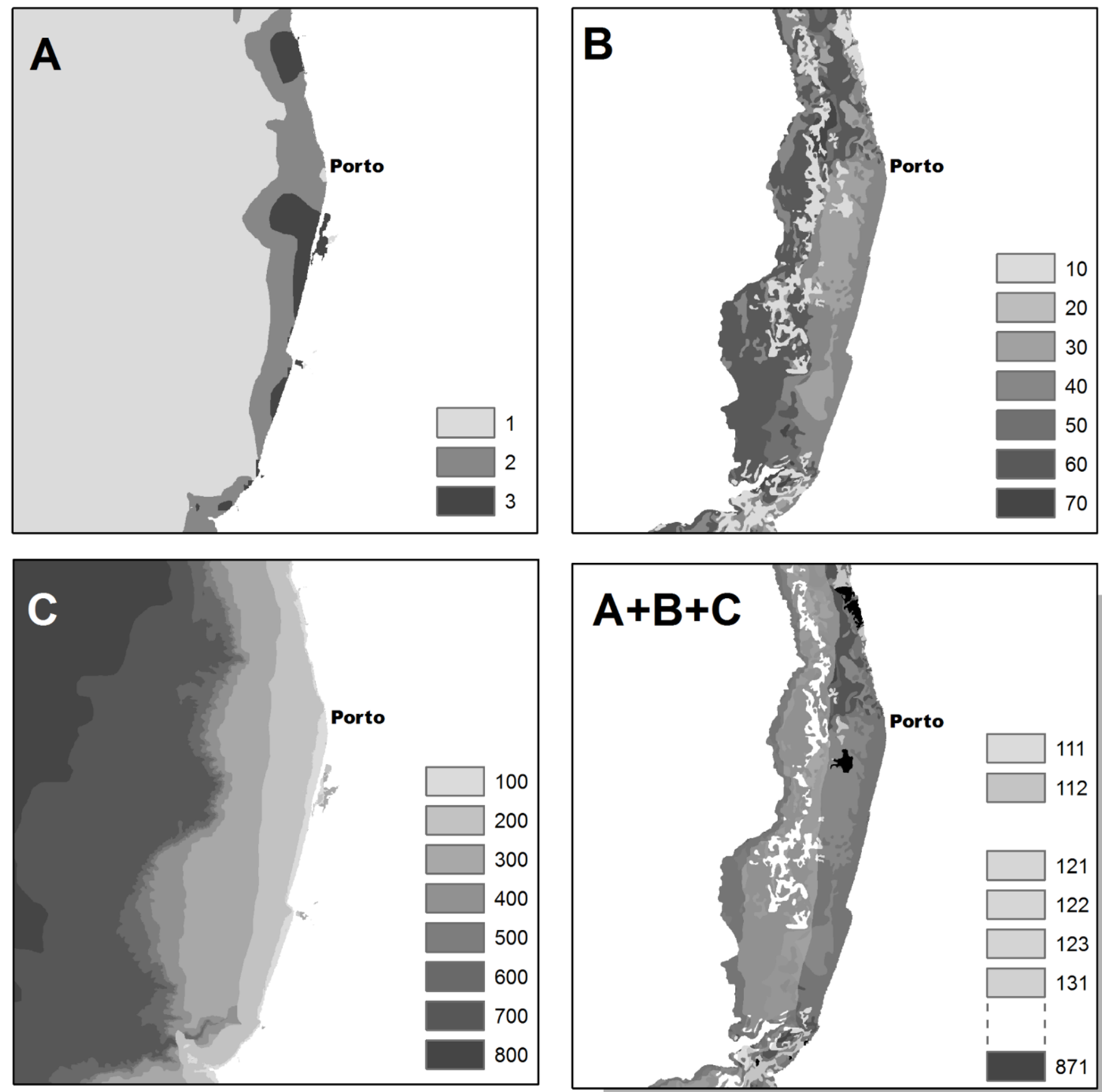

Fig. 4. Schematic representation of method for coding the three environmental characteristics (A- energy level; B- substrate type; C- biological zone) in a GIS environment and combining them in a simple additive process to derive a habitat map (bottom right).

\subsection{Confidence assessment}

The MESH project developed a confidence assessment method for historical habitat maps based on metadata (MESH, 2008). The method involved giving a score to a habitat survey map based on criteria such as vintage, survey techniques used and interpretation techniques. This method was later adapted to substrate maps by the EMODnet Geology project (Stevenson, 2011). For the purposes of the present study, a pragmatic approach that could be easily applied by all contributors was required. The 
rationale was therefore to apply a broad-scale assessment with an approach similar to the MESH method to each primary layer, namely energy, substrate type, and biological zones.

There is typically little information provided on the reliability of energy values computed from wave and current hydrodynamic models. As energy data is only used for rocky habitats it plays a minimal role in the final broad-scale map. Therefore, it was assumed that the confidence in energy layers would remain marginal in an overall assessment.

A confidence assessment of the substrate type layer was made using a modified version of the MESH confidence assessment tool (Mata Chacón et al., 2013). It was done on an individual map basis, with fourteen parameters divided into three categories collated from map metadata: five parameters describing the remote sensing surveys, five others for the collection of field data and another four accounting for the quality of the map-making process. These parameters enabled the data to be scored from 1 (lower) to 3 (higher), which were subsequently summed and expressed as a value between 0 and 100 .

The segmentation of biological zones relies mainly on the bathymetry layer. The percentage of surface light reaching the seafloor and the $\lambda / \mathrm{h}$ ratio, used for defining the infralittoral and the circalittoral lower limits respectively, are a function of the depth, while the other boundaries were defined either directly by depth contours or by variation in slope delineated from depth derivatives. The spatial patterns in biological zones are therefore directly affected by the quality of the bathymetric layer, and for an initial approximation, we used a depth quality index as a proxy to confidence in those patterns. It made sense to use the same methodology as the EUSeaMap project when making the assessment of the confidence in the bathymetry layer (Cameron and Askew, 2011). The assessment of each dataset that was used to develop the bathymetry gridded layer was carried out using three criteria that were scored separately (data resolution or density, vintage, and origin). Each criterion was scored between 1 (low) and 3 (high), yielding a bathymetry confidence score between 3 and 9 (Mata Chacón et al., 2013).

In order to have comparable values between substrate and bathymetry confidence scores, the range of values of the latter (3-9) was converted into the range of confidence values of the former (0-100). Since both maps now displayed the same range of values, they could be merged via an un-weighted average.

\section{Results}

\subsection{Raw data and base layers}

The three base layers, and the raw layers from which they are derived - such as wave-induced energy, light attenuation, or bathymetry - are not simply intermediate layers for the habitat map. They also constitute genuine products, as important as the habitat map since they provide full-coverage information for the entire study area on topics that are of interest to marine applications, both from a research and an industry perspective (e.g. extractive industries). An example of those layers are given in Figure 5. 

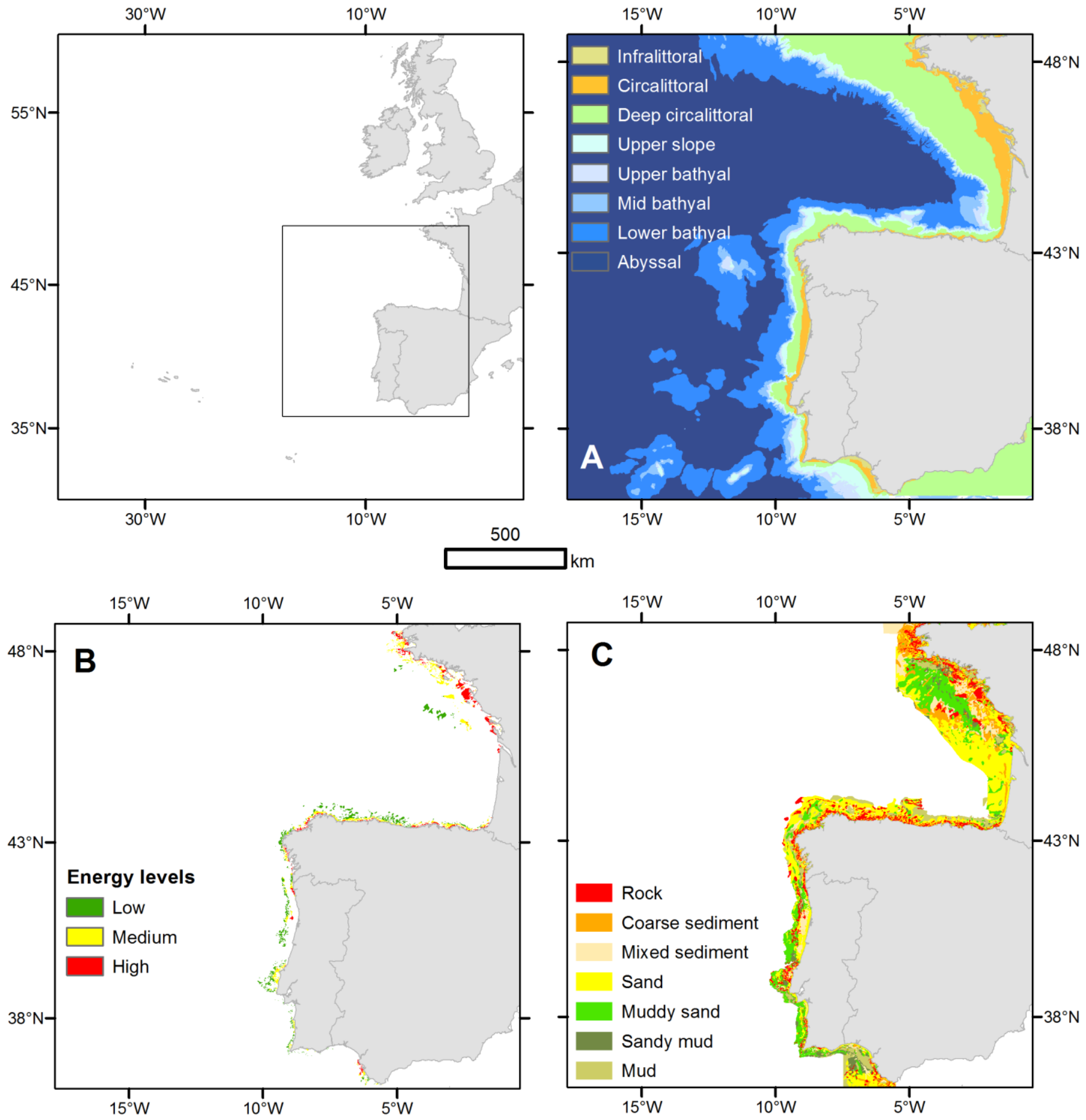

Fig. 5. Primary layers for Bay Biscay and Iberian Peninsula. (A) biological zones, (B) energy levels (for rocky habitats only) and, (C) Seafloor substrate.

\subsection{Habitat map}

The spatial distribution of habitats is displayed in Figure 6. The area and the percentage area that are covered by each habitat are detailed in the annex and summarized as a bar graph in Figure 7. The results are split into three regions for which environmental condition were deemed comparable at a broad scale. 
In the Bay of Biscay and the Iberian Peninsula, the area of shelf mapped is $132,000 \mathrm{~km}^{2}$. In contrast to this the coverage for the deep sea in these regions is only $37,500 \mathrm{~km}^{2}$. This difference is due to lack of information on substratum below the shelf, with exception of those areas along the Spanish coast where the shelf is narrower. Rocky habitat patterns are patchy but are present all along the coast and cover a large area $\left(16,800 \mathrm{~km}^{2}\right)$. On those habitats the energy is rather high in the infralittoral zone while it is moderate to low in the circalittoral zone. Deep circalittoral sand is the habitat that covers the largest areas $\left(55,671 \mathrm{~km}^{2}\right)$, especially off the coast of France. Other habitat types covering a large extent are circalittoral fine sand, deep circalittoral mud and upper slope sand to muddy sand. Coarse sediment is also widely distributed, especially in the circalittoral and deep circalittoral.

The areas of shelf and deep sea within the study area around Ireland were calcultated as $100,000 \mathrm{~km}^{2}$ and $180,000 \mathrm{~km}^{2}$ respectively. There was not any data available for substrate type for the western and north-western areas that appear as not mapped. The figures (area and percentage area) given below, in Figure 7 and in the annex are relative to the area around Ireland that is mapped, i.e. not relative to the entire Irish seas. The deep circalittoral covers the majority of the shelf (95\%). This is explained by the fact that the shelf is steep all along the coast, and thus seafloor areas not affected by wave action are very close to the shore. Rocky habitats cover $4,350 \mathrm{~km}^{2}$ and are essentially present along northwestern and southwestern coasts. These habitats are exposed to high energy in the infralittoral and moderate to low energy in the circalittoral. The deep cicalittoral is mainly composed of sand $\left(53,500 \mathrm{~km}^{2}\right)$, coarse sediment $\left(23,300 \mathrm{~km}^{2}\right)$, and mud $\left(13,200 \mathrm{~km}^{2}\right)$. In the deep sea, the most extensive habitat types are 'upper slope sand to muddy sand' $\left(35,600 \mathrm{~km}^{2}\right)$, 'lower bathyal sand to muddy sand' $\left(77,200 \mathrm{~km}^{2}\right)$ and 'lower bathyal mud to sandy mud' $\left(45,700 \mathrm{~km}^{2}\right)$. The former reflects the Porcupine Bank while the latter two are found exclusively in the Rockall Trough.

An area of $1,676,000 \mathrm{~km}^{2}$, which corresponds to $80 \%$ of the entire study area, was covered around the Azores. Shelves around the islands are quite narrow, and represent only an area of $1500 \mathrm{~km}^{2}$, half of which is composed of rocks and one third of mixed sediment. Most of the infralittoral rocks are highly exposed to wave action. However, moderate regime is also significantly present. By contrast wave action on circalittoral rocks is fairly low. The study area covers $1,660,000 \mathrm{~km}^{2}$ of deep sea, of which $75 \%$ is abyssal. Hard substrate is found in each deep-sea biological zone, but most extensively in the abyssal $\left(9,900 \mathrm{~km}^{2}\right)$. Likewise mixed sediments are present at each depth level, but the largest area is in the mid-bathyal $\left(11,000 \mathrm{~km}^{2}\right)$. As expected, the most extensive habitat types are muddy ones, which cover $94,700 \mathrm{~km}^{2}$ in the mid-bathyal, $260,500 \mathrm{~km}^{2}$ in the $10 \mathrm{wer}$ bathyal, and $1,247,000 \mathrm{~km}^{2}$ in the abyssal, the latter representing $75 \%$ of the whole area covered for the Azores. 


\section{Eunis habitats}

A3.1

A3.2

A5.13

A5.14

A3.

A4. 1

A4.2 A5.4

A4.3 A5.45

100200

400

\section{Non-Eunis deep-sea habitats}

\begin{tabular}{l|l|l|l|l|l|l}
1 & 6 & 11 & 16 & 21
\end{tabular}

\begin{tabular}{ll|l|l|l|l}
2 & 7 & 12 & 17 & 22
\end{tabular}

\begin{tabular}{l|l|l|l|l|l|l|l|l}
3 & 8 & 13 & 18 & 23
\end{tabular}

\begin{tabular}{ll|l|l|l|l}
4 & 9 & 14 & 19 & 24
\end{tabular}

\begin{tabular}{ll|l|l|l|l|}
\hline 5 & 10 & 15 & 20 & 25
\end{tabular}

Shelf edge

\section{km}
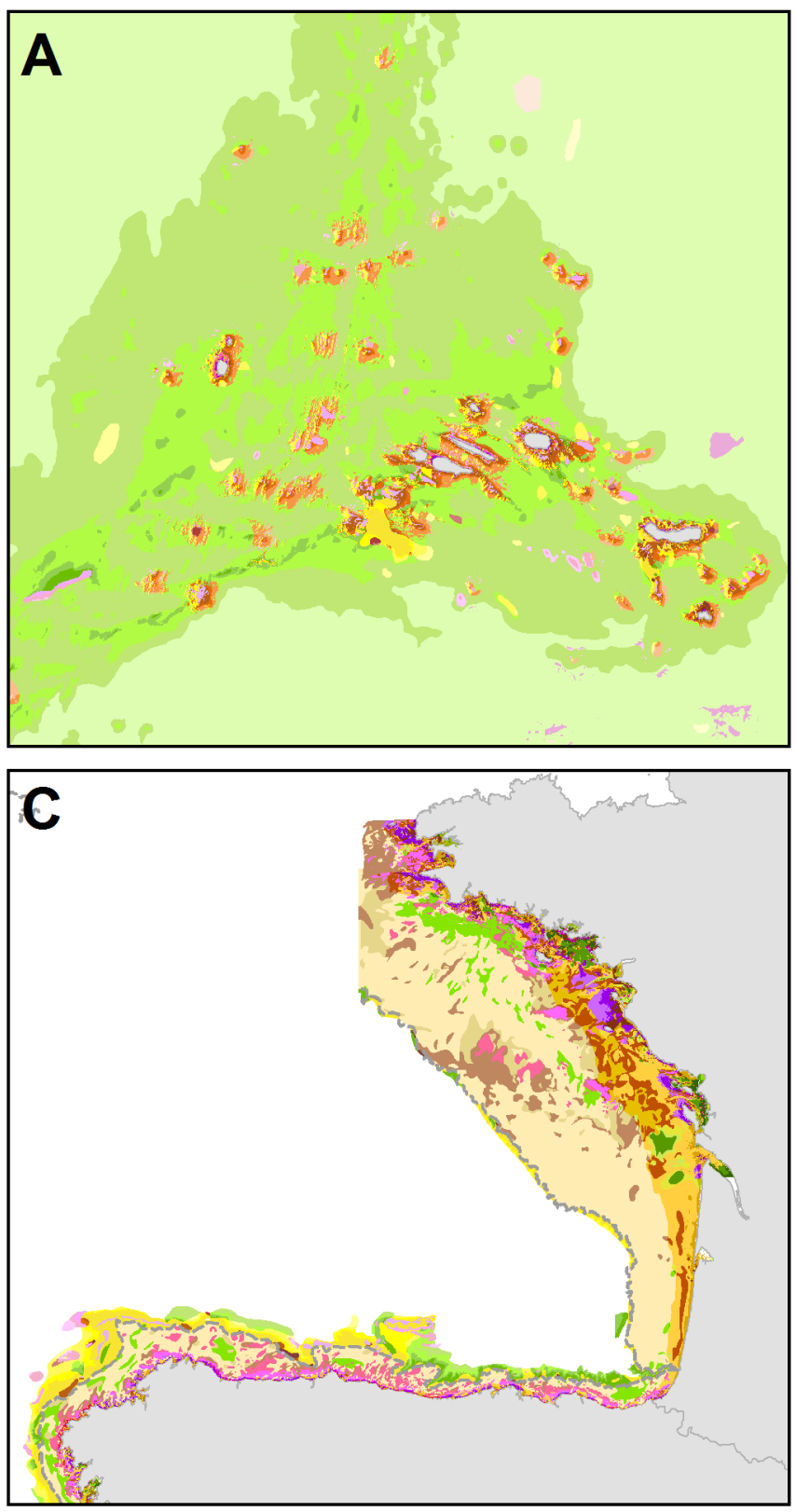
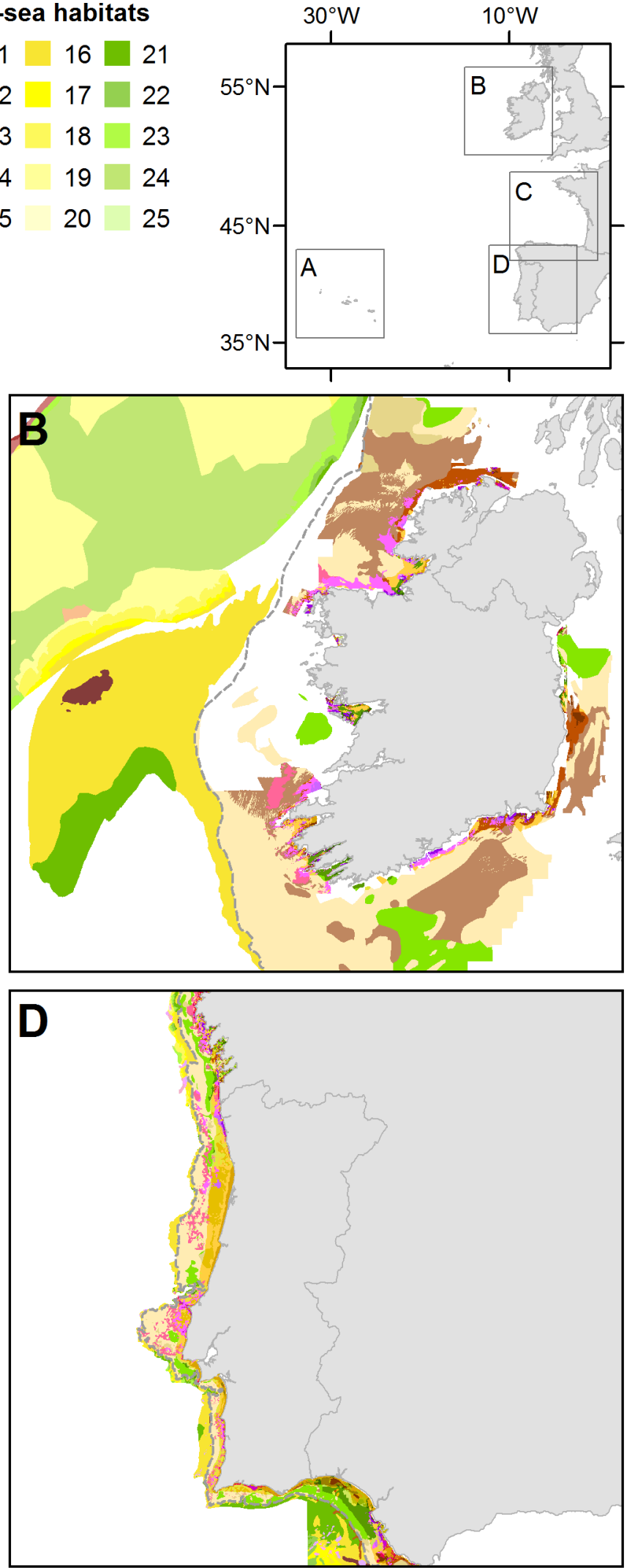

Fig. 6. Habitat map arbitrarily split into four regions (A: Azores; B: Ireland; C: Bay of Biscay; D: Iberian coast). The scale is identical for all regions. The shelf edge line shows the boundary between the shelf and the deep sea. The look up table between codes and class names is given in the annex. 


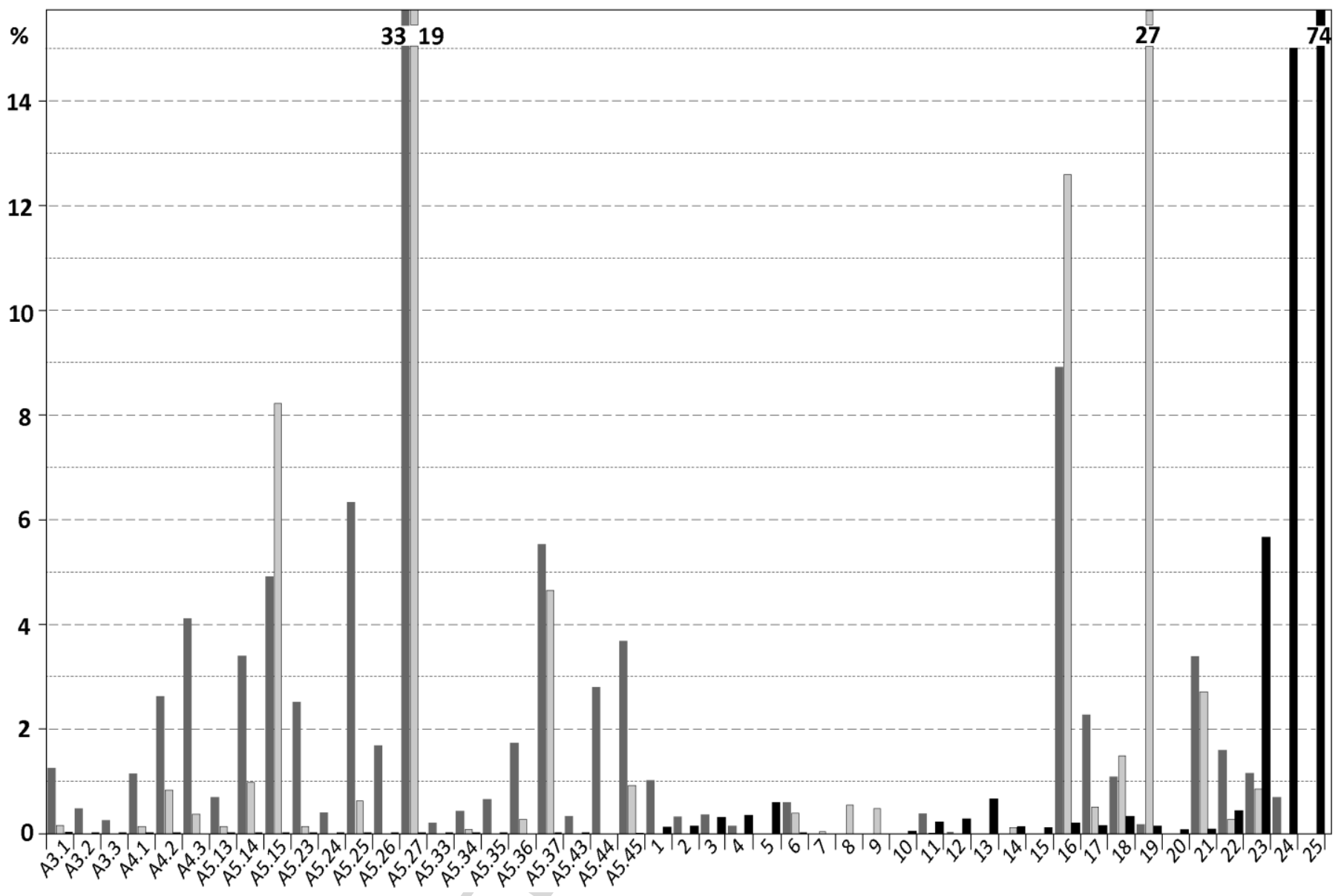

Fig. 7. Percentage area covered by each habitat. Results are split into three regions: Azores (black bars); Bay of Biscay and Iberian Peninsula (dark grey bars); Ireland (light grey bars). The look up table between codes, class names, percentages and areas is given in the annex.

\subsection{Confidence}

The confidence map is presented in Figure 8. Extensive areas of minimal confidence, such as the southern part of Ireland or the deep waters of the Azores deep waters usually correspond to areas where the GEBCO dataset - pixel size of which is coarser was widely used. Elsewhere, scores are typically in the range of 60 to 75 , except where extensive mapping programs using recent techniques have been carried out, as is the case in Ireland, where two national seafloor mapping projects have been undertaken - INSS and its successor INFOMAR. 


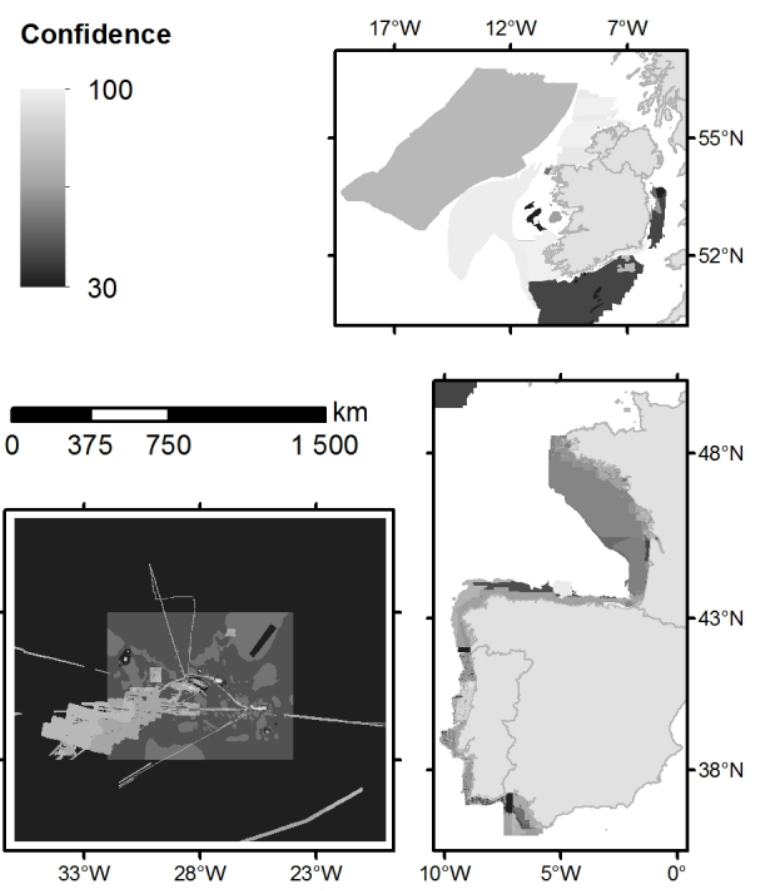

Fig. 8. Confidence map for Irish waters (upper right), Bay of Biscay and the Iberian Peninsula (lower right), and the Azores (lower left). Confidence is expressed as a score between 30 (low) and 100 (high)

\section{Discussion and conclusion}

Spatial datasets describing the physical characteristics of the seafloor were combined to produce a broad-scale habitat map for four extensive areas, using a methodology that employed the best current knowledge and relies on EUNIS, a classification system widely used across Europe by managers and scientists. By integrating new datasets with improved accuracy, the quality of the broad-scale maps that had been produced for Irish and French seafloor in previous studies was enhanced. For the waters around the Azores, mainland Portugal and Spain, the study provided the first comprehensive perception of the distribution of habitats at a broad scale.

The means of assessing confidence in the final habitat map might not be the most robust, as i) it is a subjective assessment and ii) it is based solely on confidence in the bathymetry and the substrate type data. A better approach might be to compute a probability raster based on statistical validation for each underlying layer (i.e. substrate type, bathymetry, light, wave wavelength, wave- and current-induced energy). This method was tested by the UKSeaMap project (Mc Breen et al., 2011) for the wave- and the current-induced energy layers. The main obstacle to making such a meaningful confidence assessment for the present study is the fact that most layers were an almagamation of many disparate datasets, each of which had a different provenance. The approach would have required each data provider to compute and provide a probability raster for their dataset, which is likely to be unattainable. At least the confidence map produced by the present study shows where the result are likely to be most accurate given the quality of the two key underlying layers that are the bathymetry and the substrate type. It is important to note that the score given by the confidence map at a given location does not give a percentage of chance that the mapped habitat is right, but a score expressing the confidence in the two layers.

The approach for the identification of the threshold values that define the boundaries between EUNIS categories was ecologically-driven, inasmuch as it relied on statistical analyses of observational data specific to each category. This gives an 
added confidence to threshold values. Unfortunately, due to lack of readily available sample data, most of the threshold values could not be determined in this way. However, the use of the ROC curve is a recommendation of the current study to identify the optimal cutoff value that corresponds to a boundary between two categories when sample data is available for both categories.

Based on the experience gained from this research, future improvements to the resulting habitat map can be expected in the following areas: i) In the Iberian Peninsula and the Azores improved accuracy could be obtained for the definition of energy levels if models of tide or waves were of better resolution than those used for the purposes of the study (4 km). In this way the map might show more patterns of high energy thanks to e.g. the ability of fine resolution wave models to capture wave breaks. An along-shore pixel size of $250 \mathrm{~m}$ would be optimal, but a $1 \mathrm{~km}$ resolution would also be adequate. ii) wave- and currentinduced energy layers would be greatly improved if they were based on unique models (i.e. one for waves, and another for currents). Using results from a single model would ensure coherence in the resolution and in the methodologies used for modeling. The authors of the current paper would like to encourage initiatives of high resolution (e.g. 200-300m nearshore, 3$4 \mathrm{~km}$ offshore) modeling done at a European scale. iii) Threshold values of enhanced accuracy could be calculated, particularly for energy levels on rocky habitat. Studies to date, the present one included, have relied on limited field data specific to each wave-induced anergy level, and have not validated the thresholds for current-induced energy levels suggested by McBreen et al., 2011. There would be a great potential for improvement if more sample data specific to each wave- or current-induced energy level was collated, something which was not possible during the course of this study. Likewise the threshold value for the boundary between the circalittoral and the deep circalittoral was backed up with a lot of observational data, but which was located in a relatively small French area. This value would be more reliable if it was confirmed by sample data located elsewhere. iv) The question of which variables should be used as proxies needs to be furthered. An example is the use of temperature conditions rather than the wave base for the definition of circalittoral/deep circalittoral boundary (see Glémarec, 1973). Likewise, a proxy for disturbance that would not only consider the magnitude of water movements, but also frequency, might be more relevant. v) The method used did not consider geomorphic features (e.g. seamounts, canyons). Since geomorphic features are acknowledged to host specific communities (e.g. Rogers, 1994), it is widely accepted that this information should be considered.

The main limitation to the resulting habitat map is its scale, 1:1,000,000. This makes it relatively unhelpful for local management applications. However it might be considered relevant for other applications within the study area. For example, benthic habitat maps are being used for Marine Protected Areas designation under different frameworks (e. g. Habitats Directive or OSPAR) according to different criteria such as representativity and adequacy, which should lead to the sustainable protection of relevant habitats and species. In addition to this the habitat map could be used for an assessment of the coherence of the existing MPA Networks (e.g. Natura 2000). The habitat map produced by the current study was used in that way by the Interreg IVB 'Atlantic Area 2007-2013' MAIA project (unpublished), the goal of which was to identify best practice methods for the identification, implementation and management of MPAs.

It is acknowledged the need of diverse, healthy and extensive benthic habitats areas to support the provision of important and valuable ecosystem services (i.e. food provisioning, disturbance prevention, nutrient cycling, etc.). Mapping seafloor habitats and assessing the ecosystem services they provide is a highly valuable means for understanding their current and potential benefits to society (Galparsoro et al., 2014). Habitat mapping has contributed to an improvement in the knowledge and application of several criteria and indicators used to assess environmental status in the European Marine Strategy Framework Directive (MSFD) in relation to the biological diversity descriptors, such as non-indigenous species and seafloor integrity (Borja 
et al, 2011; Galparsoro et al., 2013). It might also be useful for other descriptors and for the development of sampling design for monitoring purposes. In addition to this, the MFSD requires the Member States to assess impacts due to pressure exerted by human activities. Assessing the quantity and distribution of anthropogenic impacts could be undertaken by intersecting spatial data of human pressures and seafloor habitats (Korpinen et al., 2013). Similarly, seafloor habitat maps provide a key information for present and future offshore activities placement such as fisheries, aquaculture and renewable energy installations (Douvere and Ehler, 2009).

In conclusion, although broad-scale maps will never completely replace higher-quality, finer-resolution and more informative habitat maps derived from direct observations, needed for regional to local ocean management, they have the advantage of providing immediate resources to guide decision-makers involved in marine spatial planning in their search for solutions for sustainable development. The maps produced in this study, together with those compiled under the EUSeaMap project for Baltic, North, Channel, Irish and western Mediterranean sea basins, provide an improved perception of the spatial distribution of habitats across Europe than was available a few years ago.

The seafloor habitat layer is available online at http://www.searchmesh.net. For the other layers a specific demand should be made by email to the corresponding author.

\section{Acknowledgments}

We would like to thank all people, organisations and institutions - too numerous to mention - that provided us with substrate and bathymetry data. Further details on data origins are given in Mata Chacón et al. (2013).

We acknowledge Fabrice Ardhuin, Mickael Accensi, Fabrice Lecornu, Lucia Pineau-Guillou, Manuela Juliano, Anabela Simões and Ramiro Neves for supplying wave and currents data.

We thank Franck Dumas for assistance as expert in hydrodynamics processes. Jean-François Le Roux and Sébastien Theetten assisted with the tools used in this study, and Pierre Bodenes in the preparation of the figures.

We also thank Daniel Gorman, Amelia Curd, and two anonymous reviewers for helpful comments that improved the manuscript.

This work was carried out under the MeshAtlantic project funded by the Interreg IVB 'Atlantic Area 2007-2013' program.

Fernando Tempera was supported by the Foundation for Science and Technology (FCT-IP, Portugal) post-doctoral grant (SFRH/BPD/79801/2011). IMAR-DOP/UAz is Research and Development Unit no. 531 and LARSyS-Associated Laboratory no. 9 funded by the Portuguese Foundation for Science and Technology (FCT) through multi-annual and programmatic funding schemes (OE, FEDER, POCI2001, FSE) and by the Azores Directorate for Science and Technology (DRCT) through funding schemes (FEDER, POCI2001, FSE, COMPETE and project PEst-OE/EEI/LA0009/2011).

\section{References}

Amorim, P., Atchoi E., Tempera, F., in this volume. Infralittoral mapping around an oceanic archipelago using MERIS FR satellite imagery and deep kelp observations: A new tool for assessing MPA coverage targets.

Andersen, J.H., Stock, A. (eds.), Mannerla, M., Heinänen, S., Vinther, M., 2013. Human uses, pressures and impacts in the eastern North Sea. Aarhus University, DCE - Danish Centre for Environment and Energy. 136 pp. Technical Report from DCE - Danish Centre for Environment and Energy No. 18. Available online at http://www.dmu.dk/Pub/TR18.pdf. 
Borja, Á., I. Galparsoro, X. Irigoien, A. Iriondo, I. Menchaca, I. Muxika, M. Pascual, I. Quincoces, M. Revilla, J. Germán Rodríguez, M. Santurtún, O. Solaun, A. Uriarte, V. Valencia, I. Zorita, 2011. Implementation of the European Marine Strategy Framework Directive: A methodological approach for the assessment of environmental status, from the Basque Country (Bay of Biscay). Marine Pollution Bulletin 62, 889-904. doi: 10.1016/j.marpolbul.2011.03.031

Brown, C.J., Smith, S.J., Lawton, P., Anderson, J.T., 2011. Benthic habitat mapping: A review of progress towards improved understanding of the spatial ecology of the seafloor using acoustic techniques. Estuarine, Coastal and Shelf Science 92, 502-520. doi: 10.1016/j.ecss.2011.02.007.

Cameron, A., Askew, N. (eds.), 2011. EUSeaMap - Preparatory Action for development and assessment of a European broad-scale seabed habitat map final report. Available online at http://jncc.gov.uk/euseamap.

Carney R.S., Haedrich R.L., 1983. Zonation of fauna in the deep sea, in: Rowe G.T. (Ed.), The Sea, vol. 8: Deep-sea Biology. Wiley, New York, pp 371-398.

Castric-Fey, A., Girard-Descatoire, A., Lafargue, F., L'Hardy-Halos, M.-T., 1973. Etagement des algues et des invertébrés sessiles dans l'Archipel de Glénan. Helgolander Wiss. Meeresunters 24, 490-509.

Coltman, N., Golding, N., Verling, E., 2008. Developing a broadscale predictive EUNIS habitat map for the MESH study area. 16 pp. Available online at http://www.searchmesh.net/pdf/MESH\%20EUNIS\%20model.pdf.

Connor, D.W., Brazier, D.P., Hill, T.O., Northen, K.O., 1997a. Marine Nature Conservation Review: marine biotope classification for Britain and Ireland. Volume 1. Littoral biotopes. Version 97.06. JNCC Report, No. 229.

Connor, D.W., Dalkin, M.J., Hill, T.O., Holt, R.H.F., Sanderson, W.G., 1997b. Marine Nature Conservation Review: marine biotope classification for Britain and Ireland. Volume 2. Sublittoral biotopes. Version 97.06. JNCC Report, No. 230.

Connor, D.W., Allen, J.H., Golding, N., Howell, K.L. Lieberknecht, L.M., Northen, K.O., Reker, J.B., 2004. The Marine Habitat Classification for Britain and Ireland. Version 04.05. Joint Nature Conservation Committee, Peterborough.

Davies, C.E., Moss, D., Hill, M. O., 2004. EUNIS Habitat Classification Revised. Report to the European Topic Centre on Nature Protection and Biodiversity, European Environment Agency. 310pp. Available online at http://eunis.eea.europa.eu/upload/EUNIS_2004_report.pdf.

Dinter W., 2001. Biogeography of the OSPAR Maritime Area. German Federal Agency for Nature Conservation, Bonn. 167 pp.

Douvere, F., Maes, F., Vanhulle, A., Schrijvers, J., 2007. The role of marine spatial planning in sea use management: The Belgian case. Marine Policy 31, 182-191. doi: 10.1016/j.marpol.2006.07.003.

Douvere, F., Ehler, C.N., 2009. New perspectives on sea use management: Initial findings from European experience with marine spatial planning. Journal of Environmental Management 90, 77-88. doi: 10.1016/j.jenvman.2008.07.004

Dunn, D.C., Halpin P.N., 2009. Rugosity-based regional modeling of hard-bottom habitat. Marine ecology progress series 377, 1-11. doi: 10.3354/meps07839.

Ehrhold, A., Hamon, D., Guillaumont, B., 2006. The REBENT monitoring network, a spatially integrated, acoustic approach to surveying nearshore macrobenthic habitats: application to the Bay of Concarneau (South Brittany, France). ICES J. Mar. Sci. 63, 1604-1615. doi: 10.1016/j.icesjms.2006.06.010.

Folk, R.L., 1954. The distinction between grain size and mineral composition in sedimentary rock nomenclature. Journal of Geology 62, 334359.

Galparsoro, I., Borja, A., Uyarra M.C., 2014. Mapping ecosystem services provided by benthic habitats in the European North Atlantic Ocean. Front. Mar. Sci., 1-23. doi:10.3389/fmars.2014.00023

Galparsoro, I., Connor, D.W., Borja, Á., Aish, A., Amorim, P., Bajjouk, T., Chambers, C., Coggan, R., Dirberg, G., Ellwood, H., Evans, D., Goodin, K.L., Grehan, A., Haldin, J., Howell, K., Jenkins, C., Michez, N., Mo, G., Buhl-Mortensen, P., Pearce, B., Populus, J., Salomidi, M., Sánchez, F., Serrano, A., Shumchenia, E., Tempera, F., Vasquez, M., 2012. Using EUNIS habitat classification for benthic mapping in European seas: Present concerns and future needs. Marine Pollution Bulletin 64, 2630-2638. doi: 10.1016/j.marpolbul.2012.10.010

Galparsoro, I., Borja, Á., Kostylev, V.E., Rodríguez, J.G., Pascual, M., Muxika, I., 2013. A process-driven sedimentary habitat modelling approach, explaining seafloor integrity and biodiversity assessment within the European Marine Strategy Framework Directive. Estuarine, Coastal and Shelf Science 131, 194-205. doi: 10.1016/j.ecss.2013.07.007

Gilliland, P.M., Laffoley, D., 2008. Key elements and steps in the process of developing ecosystem-based marine spatial planning. Marine Policy 32, 787-796. doi: 10.1016/j.marpol.2008.03.022.

Glémarec M., 1969. Les peuplements benthiques du plateau continental Nord-Gascogne. Thèse de Doctorat d'Etat, Paris. 167 pp.

Glémarec, M., 1973. The Benthic Communities of the European North Atlantic Continental Shelf. In: Oceanography and Marine Biology: an Annual Review 11, 263-289.

Gorman D., Bajjouk T., Populus J., Vasquez M., Ehrhold A., 2013. Modeling kelp forest distribution and biomass along temperate rocky coastlines. Marine Biology 160(2), 309-325. doi: dx.doi.org/10.1007/s00227-012-2089-0.

Guo, J., 2002. Simple and explicit solution of wave dispersion equation. Coastal Engineering 45, 71-74. doi:10.1016/S0378-3839(02)00039-X 
Halpern, B.S., Walbridge, S., Selkoe, K.A., Kappel, C.V., Micheli, F., D’Agrosa, C., Bruno, J.F., Casey, K.S., Ebert, C., Fox, H.E., Fujita, R., Heinemann, D., Lenihan, H.S., Madin, E.M.P., Perry, M.T., Selig, E.R., Spalding, M., Steneck, R., Watson, R., 2008. A Global Map of Human Impact on Marine Ecosystems. Science 319, 948-952. doi: 10.1126/science.1149345.

Hamdi A., Vasquez M., Populus J., 2010. Cartographie des habitats physiques Eunis - Côtes de France. Convention Ifremer/AAMP ${ }^{\circ}$ 09/12177764/FY. Available online at http://archimer.ifremer.fr/doc/00026/13751/

Harris, P.T., Heap, A.D., Whiteway, T., Post, A., 2008. Application of biophysical information to support Australia's representative marine protected area program. Ocean \& Coastal Management 51, 701-711. doi: 10.1016/j.ocecoaman.2008.07.007.

Hiscock, K., ed., 1996. Marine Nature Conservation Review: rationale and methods. Joint Nature Conservation Committee: Peterborough.

Howell, K.L., 2010. A benthic classification system to aid in the implementation of marine protected area networks in the deep/high seas of the NE Atlantic. Biological Conservation 143, 1041-1056. doi: 10.1016/j.biocon.2010.02.001

Huang, Z., Brooke, B.P., Harris, P.T., 2011. A new approach to mapping marine benthic habitats using physical environmental data. Continental Shelf Research 31, S4-S16. doi: 10.1016/j.csr.2010.03.012.

Kumar, R., Indrayan, A., 2011. Receiver Operating Characteristic (ROC) Curve for Medical Researchers. Indian Pediatrics 48, 277-287. doi: $10.1007 / \mathrm{s} 13312-011-0055-4$

Korpinen, S., Meidinger, M. Laamanen, M., 2013. Cumulative impacts on seabed habitats: An indicator for assessments of good environmental status. Marine Pollution Bulletin 74, 311-319. doi: 10.1016/j.marpolbul.2013.06.036

Lazure, P., Garnier, V., Dumas, F., Herry, C., Chifflet, M., 2009. Development of a hydrodynamic model of the Bay of Biscay. Validation of hydrology. Continental Shelf Research 29, 985-997. doi: 10.1016/j.csr.2008.12.017

Lüning, K., Dring, M.H., 1979. Continuous underwater light measurements near Helgoland (North Sea) and its significance for characteristic light limits in the sublittoral region. Helgoländer Wiss. Meeresunters. 32, 403-424.

Martins R., Quintino V., Rodrigues A.M., 2013. Diversity and spatial distribution patterns of the soft-bottom macrofauna communities on the Portuguese continental shelf. Journal of Sea Research 83, 173-186. doi: 10.1016/j.seares.2013.03.001.

Mata Chacón, D., Sanz Alonso, J.L., Gonçalves, J.M.S., Monteiro, P., Bentes, L., McGrath, F., Henriques, V., Freitas, R., Amorim, P., Tempera, F., Fossecave, P., Alonso, C., Galparsoro, I., Vasquez, M., Populus, J., 2013. Report on collation of historic maps. Bathymetry, substrate and habitats - MeshAtlantic Report. Spanish Institute of Oceanography. 98 pp. Available online at http://www.meshatlantic.eu/assets/files/MeshAtlantic_Report_Collation.pdf

Mateus, M., Riflet, G., Chambel, P., Fernandes, L., Fernandes, R., Juliano, M., Campuzano, F., de Pablo, H., Neves, R., 2012. An operational model for the West Iberian coast: products and services, Ocean Sci. 8, 713-732. doi:10.5194/os-8-713-2012.

McBreen, F., Askew, N., Cameron, A., Connor, D., Ellwood, H., Carter, A., 2011. UK SeaMap 2010 Predictive mapping of seabed habitats in UK waters, JNCC Report 446, ISBN 0963 8091. 103pp. Available online at http://jncc.defra.gov.uk/PDF/jncc446_web.pdf.

MESH, 2008. MESH Confidence Assessment. Available online at http://www.searchmesh.net/default.aspx?page=1635.

Monteiro, P., Bentes L., Oliveira, F., Afonso, C., Rangel, M., Gonçalves, J.M.S., in this volume. EUNIS habitat`s thresholds for the Western coast of the Iberian Peninsula.

Pérès J. M., Picard, J., 1964. Nouveau manuel de bionomie benthique de la Mer Méditerranée. Recueil des Travaux de la Station marine d'Endoume 31 (47), 5-137.

Pérès J. M., 1967. Les biocœnoses benthiques dans le système phytal. Recueil des Travaux de la Station marine d'Endoume 42 (58), 3-113.

Pearce, J., Ferrier, S., 2000. Evaluating the predictive performance of habitat models developed using logistic regression. Ecological modelling 133(3), 225-245. doi:10.1016/s0304-3800(00)00322-7.

Roberts J.J., Best B.D., Dunn D.C., Treml E.A., Halpin P.N., 2010. Marine geospatial ecology tools: an integrated framework for ecological geoprocessing with ArcGIS, Python, R, MATLAB, and C plus. Environ Model Softw 25, 1197-1207. doi:10.1016/j.envsoft.2010.03.029.

Roff, J.C., Taylor, M.E., Laughren, J., 2003. Geophysical approaches to the classification, delineation and monitoring of marine habitats and their communities. Aquatic Conservation: Marine and Freshwater Ecosystems 13, 77-90. doi: 10.1002/aqc.525.

Rogers, A. D., 1994. The biology of Seamounts. Adv. Mar. Biol. 30, 305-350. doi: 10.1016/S0065-2881(08)60065-6

Roland, A., Ardhuin, F., 2014. On the developments of spectral wave models: numerics and parameterizations for the coastal ocean. Ocean Dynamics 64, 833-846. doi:10.1007/s10236-014-0711-z

Saulquin, B., Hamdi, A., Gohin, F., Populus, J., Mangin, A., d' Andon, O.F., 2013. Estimation of the diffuse attenuation coefficient KdPAR using MERIS and application to seabed habitat mapping. Remote Sensing of Environment 128, 224-233. doi: 10.1016/j.rse.2012.10.002.

Sing, T., Sander, O., Beerenwinkel, N., Lengauer, T, 2005. ROCR: visualizing classifier performance in R. Bioinformatics 21(20), $3940-3941$. doi: 10.1093/bioinformatics/bti623. 
Stevenson, A., 2011. Lot No 2 - Geological data - Preparatory Actions for a European Marine Observation and Data Network. Lot No 2 Geological data. Final report. Available online at: https://webgate.ec.europa.eu/maritimeforum/system/files/EMODNETGeology\%20Final\%20Report.pdf

Todd, B.J., Kostylev, V.E., 2011. Surficial geology and benthic habitat of the German Bank seabed, Scotian Shelf, Canada. Continental Shelf Research 31, S54-S68. doi: 10.1016/j.csr.2010.07.008.

Tolman, H.L., 2009. User manual and system documentation of WAVEWATCH IIITM version 3.14. National Oceanic and Atmospheric Administration, National Centers for Environmental Prediction, Ocean Modeling Branch Contribution Number 276, Camp Spring, Maryland, 110pp.

Tomlin, C.D., 1990. Geographic Information Systems and Cartographic Modeling. Englewood Cliffs, N.J. (Ed.), Prentice-Hall. 249pp.

West, N., Swift, R., Bell, C., 2010. Accessing and developing the required biophysical datasets and data layers for Marine Protected Areas network planning and wider marine spatial planning purposes: Report No 10: Task 2E. Seabed energy layers. 111pp.

Zacharias, M.A., Morris, M.C., Howes, D.E., 1999. Large scale characterization of intertidal communities using a predictive model. Journal of Experimental Marine Biology and Ecology 239, 223-242. doi: 10.1016/S0022-0981(99)00037-4 


\section{Appendix}

\begin{tabular}{|c|c|c|c|c|c|c|c|}
\hline Code & EUNIS description & $\mathrm{R} 1 \mathrm{~km}^{2}$ & R1 $\%$ & $\mathrm{R} 2 \mathrm{~km}^{2}$ & R2 \% & $\mathrm{R} 3 \mathrm{~km}^{2}$ & $\mathrm{R} 4 \%$ \\
\hline A3.1 & High energy infralittoral rock & 2090 & $1.2 \%$ & 462 & $0.2 \%$ & 131 & $0.01 \%$ \\
\hline A3.2 & Moderate energy infralittoral rock & 799 & $0.5 \%$ & 70 & $0.0 \%$ & 94 & $0.01 \%$ \\
\hline A3.3 & Low energy infralittoral rock & 423 & $0.2 \%$ & 17 & $0.0 \%$ & 55 & $0.00 \%$ \\
\hline A4.1 & High energy circalittoral rock & 1917 & $1.1 \%$ & 383 & $0.1 \%$ & 11 & $0.00 \%$ \\
\hline A 4.2 & Moderate energy circalittoral rock & 4438 & $2.6 \%$ & 2355 & $0.8 \%$ & 48 & $0.00 \%$ \\
\hline A4.3 & Low energy circalittoral rock & 6967 & $4.1 \%$ & 1067 & $0.4 \%$ & 345 & $0.02 \%$ \\
\hline A5.13 & Infralittoral coarse sediment & 1168 & $0.7 \%$ & 407 & $0.1 \%$ & 51 & $0.00 \%$ \\
\hline A5.14 & Circalittoral coarse sediment & 5753 & $3.4 \%$ & 2787 & $1.0 \%$ & 108 & $0.01 \%$ \\
\hline A5.15 & Deep circalittoral coarse sediment & 8332 & $4.9 \%$ & 23271 & $8.2 \%$ & 50 & $0.00 \%$ \\
\hline A5.23 & Infralittoral fine sand & 4261 & $2.5 \%$ & 394 & $0.1 \%$ & 107 & $0.01 \%$ \\
\hline A5.24 & Infralittoral muddy sand & 664 & $0.4 \%$ & 3 & $0.0 \%$ & 1 & $0.00 \%$ \\
\hline A5.25 & Circalittoral fine sand & 10712 & $6.3 \%$ & 1768 & $0.6 \%$ & 103 & $0.01 \%$ \\
\hline A5.26 & Circalittoral muddy sand & 2849 & $1.7 \%$ & 56 & $0.0 \%$ & 5 & $0.00 \%$ \\
\hline A5.27 & Deep circalittoral sand & 55671 & $32.8 \%$ & 53584 & $18.9 \%$ & 42 & $0.00 \%$ \\
\hline A5.33 & Infralittoral sandy mud & 355 & $0.2 \%$ & 10 & $0.0 \%$ & 0 & $0.00 \%$ \\
\hline A5.34 & Infralittoral fine mud & 703 & $0.4 \%$ & 221 & $0.1 \%$ & 0 & $0.00 \%$ \\
\hline A5.35 & Circalittoral sandy mud & 1085 & $0.6 \%$ & 4 & $0.0 \%$ & 0 & $0.00 \%$ \\
\hline A5.36 & Circalittoral fine mud & 2920 & $1.7 \%$ & 773 & $0.3 \%$ & 0 & $0.00 \%$ \\
\hline A5.37 & Deep circalittoral mud & 9387 & $5.5 \%$ & 13173 & $4.7 \%$ & 0 & $0.00 \%$ \\
\hline A5.43 & Infralittoral mixed sediments & 547 & $0.3 \%$ & 5 & $0.0 \%$ & 104 & $0.01 \%$ \\
\hline A5.44 & Circalittoral mixed sediments & 4747 & $2.8 \%$ & 0 & $0.0 \%$ & 252 & $0.02 \%$ \\
\hline A5.45 & Deep circalittoral mixed sediments & 6230 & $3.7 \%$ & 2618 & $0.9 \%$ & 100 & $0.01 \%$ \\
\hline 1 & Upper slope rock or reef & 1725 & $1.0 \%$ & 0 & $0.0 \%$ & 1970 & $0.12 \%$ \\
\hline 2 & Upper bathyal rock or reef & 544 & $0.3 \%$ & 0 & $0.0 \%$ & 2344 & $0.14 \%$ \\
\hline 3 & Mid bathyal rock or reef & 606 & $0.4 \%$ & 0 & $0.0 \%$ & 5124 & $0.31 \%$ \\
\hline 4 & Lower bathyal rock or reef & 236 & $0.1 \%$ & 0 & $0.0 \%$ & 5727 & $0.34 \%$ \\
\hline 5 & Abyssal rock or reef & 0 & $0.0 \%$ & 0 & $0.0 \%$ & 9927 & $0.59 \%$ \\
\hline 6 & Upper slope coarse sediment & 1010 & $0.6 \%$ & 1108 & $0.4 \%$ & 203 & $0.01 \%$ \\
\hline 7 & Upper bathyal coarse sediment & 28 & $0.0 \%$ & 110 & $0.0 \%$ & 254 & $0.02 \%$ \\
\hline 8 & Mid bathyal coarse sediment & 45 & $0.0 \%$ & 1562 & $0.6 \%$ & 281 & $0.02 \%$ \\
\hline 9 & Lower bathyal coarse sediment & 3 & $0.0 \%$ & 1367 & $0.5 \%$ & 320 & $0.02 \%$ \\
\hline 10 & Abyssal coarse sediment & 0 & $0.0 \%$ & 0 & $0.0 \%$ & 790 & $0.05 \%$ \\
\hline 11 & Upper slope mixed sediment & 633 & $0.4 \%$ & 27 & $0.0 \%$ & 3748 & $0.22 \%$ \\
\hline 12 & Upper bathyal mixed sediment & 35 & $0.0 \%$ & 0 & $0.0 \%$ & 4636 & $0.28 \%$ \\
\hline 13 & Mid bathyal mixed sediment & 0 & $0.0 \%$ & 0 & $0.0 \%$ & 11027 & $0.66 \%$ \\
\hline 14 & Lower bathyal mixed sediment & 0 & $0.0 \%$ & 349 & $0.1 \%$ & 2144 & $0.13 \%$ \\
\hline 15 & Abyssal mixed sediment & 0 & $0.0 \%$ & 0 & $0.0 \%$ & 1860 & $0.11 \%$ \\
\hline 16 & Upper slope sand to muddy sand & 15101 & $8.9 \%$ & 35599 & $12.6 \%$ & 3347 & $0.20 \%$ \\
\hline 17 & Upper bathyal sand to muddy sand & 3847 & $2.3 \%$ & 1444 & $0.5 \%$ & 2575 & $0.15 \%$ \\
\hline 18 & Mid bathyal sand to muddy sand & 1830 & $1.1 \%$ & 4221 & $1.5 \%$ & 5544 & $0.33 \%$ \\
\hline 19 & Lower bathyal sand to muddy sand & 294 & $0.2 \%$ & 77208 & $27.3 \%$ & 2108 & $0.13 \%$ \\
\hline 20 & Abyssal sand to muddy sand & 0 & $0.0 \%$ & 0 & $0.0 \%$ & 636 & $0.04 \%$ \\
\hline 21 & Upper slope mud to sandy mud & 5746 & $3.4 \%$ & 7648 & $2.7 \%$ & 1322 & $0.08 \%$ \\
\hline 22 & Upper bathyal mud to sandy mud & 2699 & $1.6 \%$ & 780 & $0.3 \%$ & 7339 & $0.44 \%$ \\
\hline 23 & Mid bathyal mud to sandy mud & 1968 & $1.2 \%$ & 2411 & $0.9 \%$ & 94675 & $5.65 \%$ \\
\hline 24 & Lower bathyal mud to sandy mud & 1176 & $0.7 \%$ & 45709 & $16.2 \%$ & 260436 & $15.53 \%$ \\
\hline \multirow[t]{2}{*}{25} & Abyssal mud to sandy mud & 0 & $0.0 \%$ & 0 & $0.0 \%$ & 1246973 & $74.36 \%$ \\
\hline & & 169,544 & $100 \%$ & 282,971 & $100 \%$ & $1,676,922$ & $100 \%$ \\
\hline
\end{tabular}

R1: Bay of Biscay and Iberian coast; R2: Irish coast; R3: the Azores 